Europe's Journal of Psychology, 7(4), pp. 569-596

www.ejop.org

\title{
Moral competence and the democratic way of living
}

\section{By Georg Lind}

University of Konstanz

Introduction

Two moral abilities are particularly important for living together in a democracy: firstly the ability of all citizens to judge and to act in accordance with their own moral principles; secondly, the ability to solve conflicts by means of fear-free discussions instead of the use of violence and the exercise of power. As research shows, both basic abilities, which are often summed up under the overall concept of moral competence, are essential for a democratic way of life and the functioning of democratic institutions. They are important for many things, e.g., for helping people in distress (not just readiness to help), for making quick decisions, learning effectively, for tolerating ambiguity, and for rejecting violence as a means of social change. Research also shows that the school promotes moral competence less effectively and less sustainably than is needed and seems possible today.

In this editorial, I attempt to give a broad overview on the research on moral competence and its application in education and educational policy-making in the past thirty years, in which I have been personally involved. It is not a comprehensive handbook article, which remains to be written.

\section{Why moral competence?}

Socrates: But if this be affirmed, then the desire of good is common to all, and one man is no better than another in that respect? Menon: True.

Socrates: And if one man is not better than another in desiring good, he must be better in the power of attaining it? Menon: Exactly.

Socrates: Then according to your definition virtue would appear to be the power of attaining good. 1

\footnotetext{
I Platon: Menon (Source: Project Gutenberg)
} 
Surely, moral ideals and orientations are indispensible for moral-democratic behavior and for a democratic civil society. Without them we would have no idea how we wish to take right decisions, to live together or to be governed. Ideally they provide a basis for the solution of conflicts between needs and between opinions by means of rational reflection and free discourse, instead of the use of violence or the exercise of power. The Indian-American economist and philosopher Armatya Senn (2010) speaks of democracy through discussion. Also for the American educator Dewey (1964), democracy is more than a form of government and more than the sum total of actually existing democratic institutions; it is a life form.

Yet, we need not to be concerned about ideals and orientations. As world-wide studies have repeatedly shown, there is an overall consensus in all classes of society, countries and cultures on basic moral values such as social justice, respect, cooperation, non-violence and democracy². Some scholars even believe that these moral ideals are, at least in their core, genetically determined ${ }^{3}$. Accordingly a "transmission" of moral and democratic values is unnecessary (and, I assume, not agreeable with our democratic principles).

What is rather lacking and seems necessary is the fostering of "the power of attaining good", as Socrates, the great Greek philosopher, said more than two thousand years ago, that is, our ability to apply our moral ideals in everyday life. If this competence is missing, our moral ideals can turn into ethical absolutism, and, eventually, into morally motivated violence ${ }^{4}$. In most of us, this ability is weakly developed. This ability involves, above all, the ability to make judgments in accordance with our own moral principles and to solve conflicts non-violently through discussion, even when we deal with important issues, and when we face strong opposition and our fundamental moral principles are at stake5. We need this ability in order "to participate in social, civic and working life. To be able to deal with people coming from different social and cultural backgrounds. To be able to cope in a constructive way with conflicts. To have a knowledge, skills and attitudes needed to be active as a citizen. To participate as much as possible in civic live at local, regional, national, European and global level." ('Youth in Action'-Programs of the European Union)6

\footnotetext{
2 Lind (1986); Sen (1999); Schwarz \& Bardi (2001); McFaul (2004).

3 Baver (2008); de Waal (2009); Moll et al. (2002).

${ }^{4}$ Ishida (2006). Bandura (1991, S. 74).

5 Habermas (1983); Kohlberg (1987); Karl-Otto Apel (1990); Nussbaum (2006); Sen (2010).

6 http://www.youthpass.eu/en/youthpass/for/youth-initiatives/learn/information/kcsocial/

(19.8.11)
} 
Although research on moral competence is still relatively new, we already know a good deal about it and its significance for democratic life? ${ }^{7}$. Certain relationships have been confirmed in numerous studies, as we show below. When this competence is less developed the citizens concerned are at a disadvantage in regard to participation in democratic decision-taking or are even completely excluded. Democracy itself also suffers from a lack of this competence among its citizens; it also suffers under an unequal distribution of the competence, as this leads to some citizens winning more influence than others over the process of political decision-taking. In a democracy the constitution guarantees every citizen a say in the political process. And a civil society can only function properly if every citizen actually makes use of his/her voice in the proceedings and is in a position to hear the opinions of others $^{8}$.

\section{What is moral competence?}

Recently, the concept of "competence" has become very popular and debated, especially through international school tests like "PISA". The concept has been taken up in educational policy. "With the new educational plans (of 2004) a fundamental paradigm shift in the binding specifications for teaching at our schools will take place. Whereas the educational plans of earlier generations primarily determined what was to be taught, the new plans allege that school should stipulate the competencies that children and youths must acquire." 9

However, in much of the literature the concept of competence is not clearly, if at all, defined. Often a variety of assumptions are made on the origin, development, promotion and relevance of "competencies" without saying what is actually meant by them ${ }^{10}$. As a result of this lack of clarity there is controversy among scientists on the concept of competence ${ }^{11}$; and many practitioners have strong reservations against it, doubting that the replacement of the concept of subject knowledge (Fachwissen) through the concept of competence will improve the quality of the school system. Experts like Hans-Peter Klein, the biology educationist and chairman

\footnotetext{
${ }^{7}$ An annotated list of publications can be found in the internet: http://www.uni-konstanz.de/agmoral

8 Piaget (1973); Nussbaum (2006); Sen (2010); Roth (2010); Lind et al. (2010): Nowak \& Lind (2009).

9 http://www.bildung-staerkt-menschen.de/schule_2004/bildungsplan_kurz (15.8.2011)

10 See, inter alia, the observations of the KMK (Conference of Education Ministers) (2005) on the educational standards of the Conference of Education Ministers and the 260-page-long survey on the "promotion of social, moral and democratic competencies" (Becker, 2008).

11 Klein (2010).
} 
of the society Bildung und Wissen (Education and Knowledge) fears even a decline in the level of education ${ }^{12}$. This problem also applies to the concept of moral and democratic education. There is a great deal of cloudiness as to what it means and to how its effects can be measured ${ }^{13}$. Competencies are more than conscious subject knowledge, which can be verbalized. They include also tacit knowledge, which we characterize in everyday life as emotional knowledge, gut feeling or emotional intelligence ${ }^{14}$. When we make important decisions we ultimately decide in accordance with our feelings, particularly when taking the decision is an urgent matter and we have little time available for reflection and the collection of information. Even when we have time we still listen first to our inner voice before making our choice. Our feelings enable us to make quick and sometimes even better decisions on both technical and moral questions than if we took the time for careful reflection ${ }^{15}$.

However, conscious reasoning and subject knowledge are also important for democratic life. Reason is not just the wagging tail of emotions, as some psychologists seem to believe16. We depend on them for at least two reasons. First, we need them when our feelings fail us, for example when they suggest contradictory decisions (i.e. when we are in a dilemma), when they are ambiguous or when we are about to do something which brings our moral sense into play. In the shape of (self-)critical thinking it prevents us from doing or saying everything that occurs to us spontaneously or what we are ordered to do by others ${ }^{17}$. Second, reason and conscious reflection have the important task to shape and educate our feelings so that our feelings allow us to make the right decisions when we need them, especially when we are under pressure to decide quickly ${ }^{18}$. A sportsman, for example a javelin thrower, can train his emotional reactions so perfectly that he intuitively makes the right decision when he throws the javelin. At this moment reflection would tend to disturb him. But he would have no chance to throw well, if

\footnotetext{
12 Lind (2004b; 2004c; 2011 c).

${ }^{13} \mathrm{~A}$ few authors touch on the question of how moral-democratic competence can be defined and validly measured (Tiedemann, 2011). But most authors do not even mention this problem (see, e.g., Becker, 2008; KMK, 2009)

14 Goleman (1996). In schools both competencies are mostly again reduced to conscious conceptual knowledge, which has to be acquired, just as practice often only means theory of practice and not practice itself.

15 Gigerenzer (2008).

16 Haidt (2001).

17 Achtziger et al. (2010).

18 Lind (1989a). Even undesired emotional reactions such as prejudice can disappear when the feelings responsible for them are given the opportunity to develop further. (Wasel, 1996).
} 
he and his trainer had not continuously reflected on ways of improving his throwing technique by means of suitable exercises.

The situation is similar in the moral sphere. We also make moral decisions mostly in accordance with our feelings ${ }^{19}$. Moral feelings allow us to decide quickly and to act resolutely. But here too feelings can be deceptive or place us on the horns of a dilemma, so that conscious moral thinking is called for in order to correct moral gut feelings. Conscious, professionally schooled thinking is also necessary in order to train our moral feelings. Just as the javelin thrower needs an elaborate training program in order to be able to rely in the decisive moment on his feelings about his movements, so must we also develop and shape our moral feelings so that we can rely on them when we have to make quick decisions. Just as the development of sporting skills requires a trainer and other professional helpers, so too the development of moraldemocratic competencies (virtues in the Socratic sense) needs the help of competent helpers, that is, of parents, good friends and, above all, teachers. As research has shown, biological age alone has just as little effect as genetic disposition 20 . Opportunities must be provided for the assumption of responsibility and also guided reflection, in order to develop these competencies ${ }^{21}$.

Moral-democratic competence is indispensible for mastering life in a democratic society and, to cope with the tasks and problems we encounter in our personal surroundings (family, friends, neighbors, etc.), professions and public life. We can never know precisely which tasks life in general and the private lives of each and every one of us will bring. Therefore, subject knowledge alone cannot achieve to do this, not only because it quickly becomes obsolete in our day and age, but, above all, because our decisions and our well-being in everyday life depend not only on concepts and theories, but also on our moral feelings.

Two moral-democratic core competencies are particularly important: firstly the moral capacity of all citizens to judge and act in accordance with their own moral principles 22 and, secondly, the moral capacity to solve conflicts by means of fearfree dialogues instead of by violence or the exercise of power23. "The moral solution of conflicts of action excludes the manifest employment of force as well as 'cheap' compromises; it can be understood as a continuation of communicative action -

\footnotetext{
19 Moll et al., (2002); Haidt (2003); Prehn et al. (2008).

20 Lind (2002); Rest \& Thoma (1985).

21 Lind (2000; 2002); Schillinger (2006); Lupu (2009); Saeidi (2010).

22 "The capacity to make decisions and judgments which are moral (i.e., based on internal principles) and to act in accordance with such judgments" (Kohlberg, 1964, p. 425)

23 Habermas (1983); Apel (1990); Lind (1987; 2006b; 2011 c; Sen (2010).
} 
that is action oriented to reaching understanding - with discursive means" 24 . In order to overcome violence and war, the Dalai Lama states, we need "a century of dialogue" 25 .

\section{On the measurement of moral judgmental and discourse competence}

If we want to test any assumption about the nature of moral competence or about the efficacy of certain teaching methods, we need to be able to measure it. Otherwise, all our assumptions are solely unproven beliefs and the effects of moral education are uncertain. This is easier said than done. A person's moral competence is obviously more difficult to measure than his or her knowledge of moral norms and duties. We can rather easily find out which moral rules schoolchildren know or don't know. But it is much more difficult (and sometimes even impossible) to grasp directly their ability to behave in a moral way. On the one hand, many competencies - such as for example the ability to take on responsibility - elude detection, as they only manifest themselves in real situations later in life. Only when one is really responsible for something is it possible to show how capable one is of bearing this responsibility. Or the competence can only be revealed in forms of behavior which can only be observed in serious situations, but these cannot, for ethical and practical reasons, be subjected to testing and control. It is true that in the past experiments have been carried out to test the ability of students to resist the temptation to violate a rule or to break a law26. But such experiments are controversial for ethical reasons (they involved immoral tasks as deception themselves) as well as for scientific reasons, as in these experiments one does not measure the participants' moral functioning but the conformity of isolated acts to external standards. ${ }^{27}$

An even greater problem, however, is perhaps that the measurement of competencies requires a precise knowledge of their nature, which we do not have in many areas, and experimental diagnostic techniques whose development calls for creativity, time and money ${ }^{28}$. Attempts to ignore these preconditions and,

\footnotetext{
24 Habermas (1983), p. 74.

25 Focus, 13.4.2011, http://www.focus.de/politik/ausland/seattle-dalai-lama-will-jahrhundert-desdialogs_aid_294793.html. (12.9.11)

26 Hartshorne \& May (1928).

27 Pittel \& Mendelsohn (1966). See also the insightful reflection by some of the most prominent experimenters in this field, namely Hartshorne and May (1928): "It is not the quality of the isolated act which distinguishes the good man from the bad, but the quality of the man as an organized and socially functioning self" (p. 413 - the very last sentence of the book).

28 The development and validation of the Moral Judgment Test (MJT), which is dealt with below, took several years, as at the same time the nature and development of moral behavior was
} 
instead, to come to grips with the competencies by means of subjective personal assessments and indirect indicators can lead to serious misjudgments and wrong measures in educational policy even when the collection of such data is "backed up" by test statistics 29 .

Because of these difficulties, the measurement of moral and discourse competence has only been thematized in science during the last few decades. Until a few years ago there were no instruments for the measurement of competencies in these areas. One had to be satisfied instead with the assessments of experts and teachers. But this was not a satisfactory solution as the criteria for these assessments remain obscure. Psychological research has provided numerous proofs that such assessments are strongly influenced by the "overall impression" of the test subjects or the belief in certain theories. Another approach was to measure moral competence by the behavior of people in accordance with external standards. This however, only measured norm conformity and not the ability of people to judge and act in conformity with their own moral principles ${ }^{30}$. The earliest scientific endeavors to find an adequate way of measuring moral competence, for example those undertaken by Jean Piaget and Lawrence Kohlberg, were based on interviews which were assessed by researchers on the basis of carefully chosen coding instructions. These assessments are often very elaborate and time-consuming and still not free of distortion in favor of the theories of the scientists involved ${ }^{31}$.

In order to provide a valid instrument for research and program evaluation, 35 years ago we, a group of researchers at the University of Konstanz, developed the first objective test for the measurement of moral-democratic competence, the Moral Judgment Test (MJT; Lind, 1978). The MJT can be objectively evaluated. Completion and evaluation require only little time, so it is also well-suited for testing the effectiveness of teaching methods. We have also developed a convenient online version which has been frequently used. It is time-saving and inexpensive and hence suitable for self-evaluation of lessons by teachers, especially as it only involves a small amount of additional work. In the meantime the MJT has been translated into almost 40 languages and is used world-wide in research and efficacy studies ${ }^{32}$.

subject to further research and consequently a new experimental measurement method had to be developed. (Lind, 1978; 1982; 2002; 2004b; 2008c; Weiß \& Zierer, 2010).

29 Linn (2000); Amrein \& Berliner (2002); Jahnke \& Meyerhöfer (2006); Lind (2004C; $2011 \mathrm{c}$ ).

30 Pittel \& Mendelsohn (1966).

31 Lind (1989b).

32 Lind $(1978 ; 2008 c)$. 
The MJT is not a test in the customary sense. It is a multivariate behavior experiment in the form of a questionnaire. Whereas in the customary tests an attempt is made to minimize individual features (so-called structural characteristics) by treating them as "measurement errors" and thus failing to take them into account, in experimental questionnaires it is precisely the structural differences in individual behavior which are of central importance ${ }^{33}$. In the MJT the participants have to evaluate the decision of the protagonists in dilemma stories and the arguments for and against their decisions (on a nine-point scale ranging from "I reject this completely" to "I entirely agree"). But the evaluation of their moral judgmental competence does not depend on "right" or "wrong" answers, or on the evaluation of the individual arguments. What counts is the overall answer pattern of the participant. Because of the special construction of the MJT it is possible to judge how strongly the subject based his assessments on the moral quality of the arguments presented and how strongly he took other aspects of the arguments into account, for example, how far the arguments corresponded to his own opinion on the case. We know from numerous studies that most people are guided in the assessment of arguments by "opinion conformity" (i.e. agree to all arguments which coincide with their own opinion and reject those which contradict their own opinion) and in controversial discussions are scarcely capable of judging arguments according to their moral quality. For democracy as discussion, i.e. for the solution of conflicts by means of peaceful, nonviolent discourse, it is indispensable that people are in a position to weigh up the arguments of opponents from a moral point of view instead of rejecting them lock, stock and barrel.

The MJT stands in contrast to approaches which attempt to assess moral competence by enquiring about attitudes and values, i.e. indirectly, and with other approaches in which action alternatives are given in dilemma situations, between which the subject has to choose. In the first case no valid measurement is possible, as what is measured is not a competence. The second approach is problematic in terms of the ethical aspects of research, as the researcher applies his own subjective standards on morality in the assessment of the test answers but does not measure whether the subject has been guided by his own moral standards. In his comprehensive study of the literature on the efficacy of teaching in philosophy and ethics, the ethics educationalist Markus Tiedemann comes consequently to the conclusion "that it has hitherto not been possible to assess ethical powers of judgments in an empirically satisfactory way"34. However, he excludes the MJT

\footnotetext{
33 Lind $(1982 ; 2008 a)$.

34 Tiedemann (2011).
} 
explicitly from this verdict, as he had only learned about it after the completion of his study, and in fact regards it as an adequate approach 35.

The significance of moral democratic competence for life in schools and civil society

As many studies have shown, moral democratic competence plays a key role in the building and maintenance of civil society: It seems that the development of this competence plays an important part in cooperative, pro-social behavior and in the ability to deal with conflict and to make decisions ${ }^{36}$. It helps to prevent criminality ${ }^{37}$, drug consumption ${ }^{38}$ and the use of violence ${ }^{39}$. According to the present state of research it can be expected that the promotion of moral competence among students (and teachers) is also directly beneficial for school learning ${ }^{40}$ and for the social climate in class and in the school community ${ }^{41}$. It strengthens the ability to have one's voice heard and to listen to others ${ }^{42}$. People with high levels of moral competence also show a stronger commitment to democracy and freedom ${ }^{43}$. These relationships are not only proved by high correlations. There are also experimental indications of causal mechanisms ${ }^{44}$.

\section{Strengthening moral competence as a task of the school}

The co-author of the American constitution and later president of the USA Thomas Jefferson (1940) saw the success of the project of a democratic society as being closely linked with the quality of its educational system. According to Jefferson a high quality education for every citizen is the best means of preventing democracy from atrophying and being replaced by an authoritarian regime. The German conference of ministers of education (Kultusministerkonferenz, 2008) described "Education for Democracy" as a central task for schools and the education of

\footnotetext{
35 Oral communication by Prof. Markus Tiedemann, Freie Universität Berlin, 28.5.2011.

36 Mansbart (2001); Prehn et al. (2008).

37 Hemmerling et al. (2009); Hemmerling (in press).

38 Lenz (2006); Lind (2011c).

39 Seitz (1991); Lind (2002).

40 Heidbrink (2010).

41 Lind $(2002 ; 2009 a)$.

42 Lind (2008a).

43 Haan et al. (1968); Gross (1997); Lind et al. (2010).

${ }_{44}$ Further references on the studies cited here can be found in the internet: http://www.unikonstanz.de/ag-moral/mut/mjt-references.htm
} 
youth ${ }^{45}$. Strengthening moral democratic competence, in particular, is regarded as a task of the schools. In answer to a question of the SPD parliamentary group, for example, the Minister for Culture, Youth and Sport of the State of BadenWurttemberg said:

"The promotion of moral and democratic competencies is an essential element of the educational reform and hence of the Educational Plan for 2004, which, in its introduction, formulates central questions on the fields "Living in Communities" and "Learning Democracy" which are binding... Teaching promotes the readiness to accept responsibility and the ability of students to make moral and political judgments. Democratic education mediates the competence to act, thereby preparing students for participation in social and political life. The students learn to take on responsibility for themselves and others in social relationships. Living together they develop the readiness to respect the rights of others and to understand the rules necessary to this end. They learn to respect other opinions and attitudes" 46 .

Of course parents, the media, friends and other instances can and should also make their contributions. But only the school provides the opportunity to promote this competence effectively and sustainably among all citizens (inclusion). The school is the only institution which is in a position to reach all children and young people and to win them for democracy" (BLK-Project Demokratie lernen und leben / Project of the Federal and State Commission Learning and Living Democracy). Charles Darwin (1966) already pointed to the school as the most important place for the promotion of moral competence. (As far as we know he was the first person to use the concept).

Whether and how far the school contributes or can contribute to the promotion of moral competence is, however, a controversial question. Often it is not even asked at all. Although many new teaching methods have found their way into teaching, some authors deny that the school can have any promotional effect on moral judgmental and discourse competence ${ }^{47}$. As we know from many studies, it is a fact that the measurable progress in moral judgmental and discourse competence is

\footnotetext{
45 KMK (2009).

46 MKJS (2004). See also: Oberschulamt Freiburg (o.J.): "Demokratie lernen und leben - ein chancenreicher Auftrag des Bildungsplans". http://www.rp.baden-

wuerttemberg.de/servlet/PB/show/1234251/rpf-ref77-chancenreicher\%20Auftrag_Demokratie.pdf (consulted on 14.8.2011)

47 Uhl (1986); Schläfli et al. (1985).
} 
much smaller and less sustainable than it could be ${ }^{48}$. Students seldom have the opportunity to accept responsibility for their actions and to experience a democratic, respectful discussion on controversial topics ${ }^{49}$. In this respect there is a substantial need in our schools (and not only there) to catch up ${ }^{50}$. As we have seen, we do not need to mediate any values ${ }^{51}$ to people - most if not all people have basic moral values. We must, however, help them to apply these values in daily life and to develop the skill they need, i.e. moral competence. In the past the teaching of democracy (political and civic education studies) and ethics was mostly restricted to the mediation of conceptual knowledge, i.e. to declarative knowledge of laws, theories and institutions. This education limited to verbal knowledge of democratic ideals is not sufficient, as we have been warned by Gustav Radbruch, a philosopher of law who has substantially and sustainably influenced our modern legal system. According to Radbruch the school must make it possible for students to experience democracy - not only democracy as a form of government with its institutions but also, and above all, democracy as a form of life and as discussion. Enabling students to experience self-determination and moral-democratic ways of dealing with others in an atmosphere free of compulsion and fear is one of the core tasks of education in and for democracy. In the teaching of politics and ethics attempts have, therefore, been made in recent years to overcome the restriction of the curricula in these subjects to the learning of the knowledge in books. Procedural action knowledge - which was previously ignored - and the emotional affective side of moral democratic behavior are being increasingly emphasized.

In this context there are two very different approaches to making democracy experiencable, namely in relation to democracy as a governmental form and to

48 Lind (2002; 2009a; 2009b).

49 In KMDD lessons I regularly ask students whether they have discussed important problems with others (parents, teachers, friends etc.) in the way we had just discussed them, but I usually receive only few positive answers. A teacher who was present at a lesson at first expressed doubts about the answers of the student but after a pause for thought she admitted that the discussions normally took a completely different course.

50 Lind (2006b).

51 The concept of "value" is ambiguous. It not only means moral basic values or moral principles, as is the case here, but also a variety of attitudes and opinions which are clearly private or culture-specific in nature and which are protected by the democratic basic law of freedom of opinion and conscience from state interference. This distinction is very important and must also be respected by schools. We must guard against mediating basic values to people who already possess them, and private and cultural values in areas over which the state has no rights. 
democracy as a life form. In regard to the understanding of democracy as a form of government (separation of powers, elections, parliamentarism, majority decisiontaking, etc.) the school can only succeed in promoting democratic attitudes and abilities if it itself adopts (at least in part) the governmental forms valid in society. It is only through democratic school assemblies and the participation of students in decisions at school, it is argued, that children can experience what democracy is and experience this form of government in a convincing way.

The great difficulty with this approach lies in the fact that in a formally democratic school the children can learn democracy as a form of government but not always as a form of life. This is the case, above all, because the transfer of a democratic governmental form assumes such a high degree of moral competence among all the participants (students, teachers, school administrators, legislators and voters) that it often meets with resistance. This can be illustrated by the fate of the SMV (Schülermitverantwortung / school council) and the still very limited dissemination of "democratic schools" 52 . The SMV's, which the occupying powers had introduced into the then West Zone after the Second World War, and the majority of the supporters of the "democratic school" movement were guided by the idea that students would learn democracy if they experience certain forms of political participation in school affairs. Another prominent example of this idea in Germany is the nationwide model project "Demokratie lernen und leben" (Learning and living democracy, 2002-2006) financed by the Bund-Länder Kommission (Federal Government/Federal States Commission for Educational Planning), which aimed at the mediation of democratic values. By creating opportunities for students to participate in lessons and school life "the readiness of young people to take an active part in civil society" was to be promoted 53 . The evaluation of this project by the German Institute for International Educational Research (DIPF) 54 revealed an increase in the readiness to participate and more positive attitudes towards democracy among the participants. The possibility that such projects also promote competence cannot be excluded. But no efficacy studies exist to demonstrate this.

One of the few approaches whose efficacy has been empirically evaluated by means of intervention studies is the Just Community approach of Lawrence Kohlberg

\footnotetext{
52 Huang (2009); Backhaus \& Knorre (2008).

53 My emphasis; GL.

54 Unfortunately it is no longer available in the internet. http://blk-

demokratie.de/programm/externe-evaluation.html. Other links to this study

(http://193.175.239.23/ows-bin/owa/r.einzeldok?doknr=36040) are also no longer valid (Consulted on 17.8.2011)
} 
and his colleagues ${ }^{55}$. In spite of the great efforts undertaken and the large degree of acceptance by the students and teachers this approach proved to have had little effect on the promotion of moral judgmental competence. "The studies we have examined which linked moral development to social studies and history seem to have brought about scarcely any real change in the moral judgmental competence", writes Ann Higgins, one of the leading scholars in this field ${ }^{56}$. In their large-scale Just Community project in New York Power, Higgins and Kohlberg found only a very weak effect after a year ${ }^{57}$. The slight increase in test scores (9.50 MMSpoints) is all the more disappointing as control students from traditional schools with no Just Community revealed a higher increase in the same period $(15.25)^{58}$. In the Just Community project carried out at three German schools, the DES Project59, a very clear growth in judgmental competence was established after a period of about 2.5 years $^{60}$. The project also revealed a reduction in dysfunctional behavior. But even when effects were recognized they could not be clearly attributed to the democratization of the school, as dilemma discussions were also carried out at the same time in all of these projects. As we know how effective dilemma discussions are, the possibility cannot be excluded that these led to the increase in test values and not so much the Just Community program.

This sobering realization has led me to rethink fundamentally the previous approaches to moral-democratic education. In view of the ineffectiveness of many of these approaches I have become convinced that democracy as a life form can be achieved more quickly and effectively in schools and society if one takes the individual as the starting point and undertakes fitting means to promote moral competence directly. According to everything we know, fundamental trust in democracy as a life form arises in young people (and adults):

a) when they deal respectfully with each other and can practice and experience a discursive, non-violent solution of problems;

b) when they experience themselves as enjoying equal rights and see that their opinion counts just as much as anyone else's and that power and status do not decide on access to information.

\footnotetext{
55 Power et al. (1989); Oser \& Althof (1994); Lind (2002; 2009);

56 Higgins (1980), p. 106.

57 "The results indicated a modest developmental change only in the two democratic high schools with teaching staffs explicitly committed to the just community approach" (Power et al., 1989, S. 297).

58 Power et al. (1989), p. 279.

59 Lind \& Raschert (1986); Oser \& Althof (1994); Lind (2002).

60 Lind (2002), p. 180.
} 
Being able to experience these things is a question of the opportunity offered to young people and of their individual ability to grasp and use this opportunity. It is, therefore, very important for the effectiveness of teaching that the opportunities provided for moral-democratic learning are well adjusted to the individual abilities. Precisely this is achieved by the Konstanz Method of Dilemma Discussion, which we developed over the past twenty years.

The promotion of moral competence with the Konstanz Method of Dilemma Discussion (KMDD) ${ }^{\circledR}$

The main aim of the KMDD is the promotion of moral-democratic competence. Put simply this means the furtherance of the ability to stand up for one's own point of view and of the capacity to listen to others when important issues are at stake, important to oneself or to another person. This also means the ability to look for and to maintain communication with others when strong moral feelings are involved on both sides. This competence is fundamental for the individual ability to solve problems and conflicts under pressure, to make decisions, to learn from experience and, above all, to cooperate with other people and to be a productive member of civil society (see below). As research has shown, the existing degree of this competence differs from person to person. In most people it is only weakly developed. They find it very difficult to engage in a dialogue with others when their counterpart expresses a different opinion or presents himself as an opponent ${ }^{61}$. This competence does not develop simply as a result of biological maturation and growing older, or under pressure from the social milieu, but evidently only when certain learning opportunities are given or society (in the shape of its educational institutions) provides such learning opportunities, either intentionally or by chance 62.

It is not only difficult to measure competencies but also to further them in a purposeful manner, as their promotion cannot be restricted to the transmission of subject knowledge but must involve applying this knowledge and taking on responsibility for the validity of this knowledge, as well as feelings and real experience. Competencies can only be acquired by active doing (Dewey). As with competence in general the difficulty in mediating moral competence consists in developing suitable tasks and exercise types which encourage students to act in a moral-democratic way. A further problem with moral-democratic educational aims is that the teaching methods (the active doing of the teacher) must be in keeping

\footnotetext{
${ }^{61}$ Keasey (1974); Habermas (1983); Lind (2002).

62 Rest \& Thomas (1985); Lind (2000; 2002); Schillinger (2006); Lupu (2009); Saeidi (2011).
} 
with these aims. Self-determination cannot be taught with compulsory methods 63 . The ability to behave in accordance with inner moral principles cannot be tested by external standards. The active doing of learners should not be prevented by excessive activity on the part of the teacher.

The KMDD has similarities with vaccination against virus infections. Just as in the case of vaccination, when the organism is confronted with real but weakened viruses in order to stimulate its ability to survive an actual virus attack, so too in the KMDD the students are confronted for learning purposes with the task of entering into a moral discourse on a moral dilemma with different-minded students and of giving arguments to convince them of their own opinion on the dilemma.

Alternating phases of support and challenge during a 90-minute KMDD session ensure that the moral feelings of the participants evoked by the controversy are kept within an optimal range. To this end special "educative" dilemmas have been constructed for KMDD sessions which are highly realistic in form and deal with controversial topics, but have fictive persons as their protagonists. KMDD sessions have only two rules: firstly, the participants can say everything they wish (except for making value judgments on others); secondly, the participants call upon one another to make contributions, i.e. there is no discussion leader or moderator. Violations of the first rule very rarely occur, but they are more frequent in the case of the second rule. In my year-long experience with various age groups, school types and cultures, I have found that it is sufficient, when violations occur, to remind the participants in a friendly way of the rule in order to guarantee its observation. This experience strengthens the assumption that the rules of the KMDD do in fact correspond to the moral feelings of most, if not of all people. The participants make the experience that all the students and also all the teachers are subject to the authority of rules instead of the power of certain persons, in accordance with the moral ideal of the "equal dignity" 64 of all people, and that they do this freely and gladly without their being any need for punishment or reward. Participants also report that in KMDD sessions they have learned to esteem people with other opinions as important and useful sources of inspiration for their own development, and not merely to tolerate them.

The KMDD method can be traced back to the work of Blatt and Kohlberg ${ }^{65}$. This method became popular in Germany as a result of the school project Demokratie

\footnotetext{
63 Portele (1978) fittingly calls this the "You ought-to-want-to paradox".

64 JuUl (1997).

${ }^{65}$ See Reinhardt, S. (1980); Lind \& Lind (1984), Lind (1987; 1989a; 1993); Lind \& Raschert (1987).
} 
und Erziehung in der Schule (DES / Democracy and Education in Schools) carried out in North Rhine-Westphalia (from 1985 to 1991), which I had initiated and led (together with Jürgen Raschert) ${ }^{66}$. The Kohlberg method turned out to be more effective than all the hitherto known teaching methods. Its effectiveness seemed to me, however, to be capable of improvement67. On the basis of the experience made with the DES project I have further developed the Blatt-Kohlberg method and have considerably increased its efficacy over the last twenty years. In this way the Konstanz Method of Dilemma Discussion $(\mathrm{KMDD})^{\circledR}$ was born, which is described in more detail below.

The KMDD is based on the insight that an effective, sustainable and, for society, functional promotion of moral competence can only succeed 68 when:

a. moral learning is made possible through the positive experience of equal dignity, i.e. of genuine freedom of speech and respect and is not (overtly or covertly) prevented by teaching methods which run counter to the learning goals (the compatibility of aims and means)69,

b. feelings and emotions are competently and responsibly integrated into the learning process by the teacher (the professionality principle),

c. students and teachers have the opportunity to receive objective, intelligible and undistorted feedback on their learning gains (the self-evaluation principle),

d. all students are furthered and inequality of opportunity for civic participation is compensated for (the inclusion principle).

The KMDD is one of the few educational methods whose efficacy has been scientifically tested by means of intervention studies with before-and-after investigations and comparative analyses. It has been shown that the moraldemocratic competence of people can be very effectively promoted with the KMDD method: Even after only a few KMDD lessons the recorded effect size is far higher than the customary effect sizes $(r>0.5 \text { bzw. } d>1.20)^{70}$. In addition, numerous

\footnotetext{
66 Lind, G. \& Raschert, J. (1987). Lind, G. (1993; 2004a; 2008a). Oser, F. \& Althof, W. (1994). 67 Lind $(1994 ; 2002 ; 2009 a)$.

68 For an introduction see: Lind, G. (2009). "Moral ist lehrbar - Handbuch zur Theorie und Praxis moralischer und demokratischer Bildung." München: Oldenbourg (2. edn.)

69 The phenomenon of the "hidden curriculum" referred to by Jackson (1967).

70 The effect sizes are far greater than the values of other methods. A value of $r=0.3$ is regarded by some as a threshold. On the conception and evaluation of the KMDD see http://www.unikonstanz.de/ag-moral/moral/kmdd-references.htm
} 
reports of participants are available in the internet which give an impression of the acceptance and confirmed effectiveness of the KMDD ${ }^{71}$.

The KMDD is well received by the participants not only because students usually enjoy discussing and because these sessions bring variety into everyday life at school. The students are also very much impressed by the good discussion culture. "We could really argue about something without it immediately becoming personal and causing aggression, as it usually does" was the judgment of a ten-year-old girl. Many participants judge their experience with KMDD lessons in a similar way. A number of media reports and video documentations on the KMDD exist72.

The KMDD has the following characteristics:

- It can be employed in all subjects and also in interdisciplinary teaching;

- Its efficacy is continuously self-evaluated with anonymous before-and-after tests through the ITSE program ${ }^{73}$. ITSE stands for Improvement of Teaching through Self-Evaluation. ITSE is an integral part of the KMDD and of the training to become a KMDD teacher. This assessment serves to assure both the quality of the teachers' work and the further development of the method. The anonymity of the data collection prevents the "inevitable corruption" of person-related evaluations ${ }^{74}$. Composite anonymous data serve as the basis for the evaluation and further development of the KMDD;

- Clinical supervision by colleagues is also an integral part of the KMDD and of the training to become a KMDD teacher. It is an important element in internal further education in schools and of quality assurance and it serves as a "window" to the outside world (other teaching staff, society), thus opening up the project to the society outside;

- The core of the examination and certification of KMDD teachers is the assessment of a "best practice video" by two experts. Here the candidate can demonstrate that he has a sovereign command of the method. The examination by means of a video is comparatively valid for the profession and fair. It is largely independent of indispositions resulting from examinations of the candidate, his class and the examiner, and can be tested by third persons in the event of objections. This part of the test can be repeated. There is no graded marking. In addition, a learning portfolio with brief reports on lessons, efficacy studies and reflections on one's own training is required.

\footnotetext{
$71 \mathrm{http}: / /$ www.uni-konstanz.de/ag-moral/moral/KMDD_rueckmeldung_teilnehmer.htm

$72 \mathrm{http}: / /$ www.uni-konstanz.de/ag-moral/moral/KMDD_rueckmeldung_medien.htm

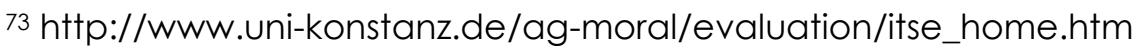

74 "Campbell's law"; see Campbell (1978); Amrein \& Berliner (2002); Nichols \& Berliner (2006); Lind (2004c; $2011 \mathrm{c})$.
} 
It can often be observed that teachers who use the KMDD change their entire behavior in their teaching. It seems that the KMDD "rubs off". This is a thoroughly desirable effect of the KMDD. The KMDD can be used in all school types (from grade three onwards) and also in other non-school educational institutions, at home and abroad75.

\section{Conclusion}

Democracy is a high moral ideal of most people worldwide. Regardless of culture, religion, age, social class, gender etc., most if not all people have high moral ideals and principles. But we also know that these are not sufficient in view of the complexity of everyday life for people to make decisions which accord with these ideals in every situation. To this end we have to develop a special ability which we have characterized here as moral competence. As the research shows, this competence can scarcely develop of its own accord, but requires encouragement by the institutions of society - parents, siblings, friends, media etc. and especially by the schools. The Konstanz Method of Dilemma Discussion provides schools with a method with which they can promote moral-democratic competence very effectively and which can be easily integrated into the curriculum of all subjects. In order to be effective, however, this method requires a thorough training in its use ${ }^{76}$.

\footnotetext{
75 Non-school educational institutions in which the KMDD has hitherto be employed: in the German Armed Forces (Bergmann, 2007), in prisons (Hemmerling, in press), in university didactics at the University of Konstanz, in medical training (Medical School of Monterrey/Mexiko, Universidad de Sao Paulo/Brazil, Universidad de Chile), at an interdisciplinary level in the Universidad de Monterrey/Mexico, in the training of ethics teachers at the University of Poznan/Poland, at the Universities of Applied Sciences for Social Work in Berlin and Zurich and at the University of Applied Sciences: Special Needs Education in Zurich.

76 A detailed presentation of the theory and implementation of the KMDD can be found, inter alia, in my book "Moral ist lehrbar"76 and on the following website: http://www.unikonstanz.de/ag-moral/. An account is also given there of the similarities and differences between the KMDD and other methods of moral and democratic education, such as the Kohlberg method, role-playing, debating clubs, etc.
} 
References ${ }^{77}$

Achtziger, A., Jaudas, A., \& Keil, A. (2010). Controlling social stereotypes. Paper presented at the Symposium "Limits of Intentionality" of the DFG Research Group "Grenzen der Absichtlichkeit", Konstanz.

Amrein, A. \& Berliner, D. (2002). High-stakes testing, uncertainty, and student learning. Education Policy Analysis Archives, 10 (18), March 28, 2002. http://epaa.asu.edu/epaa/v10n18/

Apel, K.-O. (1990). Diskurs und Verantwortung. Das Problem des Übergangs zur postkonventionellen Moral. Frankfurt: Suhrkamp.

Bandura, A. (1991). Social cognitive theory of moral thought and action. In: W.H. Kurtines \& J.L. Gewirtz, eds., Handbook of Moral Behavior and Development. pp. 65-78. Hillsdale, NJ: Erlbaum.

Baver, J. (2008). Das kooperative Gen. Munich: Heyne Verlag.

Backhaus, A. \& Knorre, S., Eds. (2008). Demokratische Grundschule. Mitbestimmung von Kindern übe ihr Leben und Lernen. Siegen: University of Siegen (self-printed).

Becker, G. (2008). Soziale, moralische und demokratische Kompetenzen fördern. Ein Überblick über schulische Förderkonzepte. Weinheim: Beltz.

Bell, J. \& Müller, Th., Eds. (2011). Wissen, was wirkt. Kritik evidenzbasierter Pädagogik. Wiesbaden: Verlag für Sozialwissenschaften.

Bergmann, R. (2007). Interview mit Brigadegeneral Bergmann über die „Konstanzer Methode der Dilemmadiskussion - ein neuer Ansatz. Kompass. Herausgegeben vom Katholischen Militärbischof für die Deutsche Bundeswehr, Ausgabe 05/07, pp. 8 - 11.

Darwin, Ch. (1966). Die Abstammung des Menschen. Translated by Heinrich SchmidtJena. (Original title, The Descent of Man. 2. edn, 1871). Stuttgart: Kröner Verlag.

Dewey, J. (1964). Demokratie und Erziehung. Eine Einleitung in die philosophische Pädagogik. Braunschweig: Georg Westermann Verlag (Original 1915).

\footnotetext{
77 All the articles marked '*' can be downloaded from: http://www.uni-konstanz.de/ag-moral/ The password sometimes needed to open files is "kohlberg".
} 
Gigerenzer, G. (2008). Bauchentscheidungen. Die Intelligenz des Unbewussten und die Macht der Intuition. München: Goldmann.

Goleman, D. (1996). Emotionale Intelligenz. München: Goldmann.

Gross, M.L. (1997). Ethics and activism: The theory and practice of political morality. Cambridge, MA Cambridge University Press.

Haan, N., Smith, M.B. \& Block, J.H. (1968). Moral reasoning of young adults: Political-social behavior, family background, and personality correlates. Journal of Personality and Social Psychology, 10, 183-201.

Habermas, J. (1983). Moralbewusstsein und kommunikatives Handeln. Frankfurt: Suhrkamp. (English publication in 1989: Moral consciousness and communicative action.)

Haidt, J. (2001). The emotional dog and its rational tail: A social intuitionist approach to moral judgment. Psychological Review 108, 4, 814-834.

Haidt, J. (2003). The moral emotions. In: R. J. Davidson, K. R. Scherer, \& H. H. Goldsmith, Eds., Handbook of affective sciences. Oxford: Oxford University Press, pp. 852-870.

Hartshorne, H. \& May, M. A. (1928). Studies in the nature of character. Vol. I: Studies in deceit. New York: Macmillan.

Heidbrink, H. (2010). Moral judgment competence and political learning. In: Lind, G., Hartmann, H.A. \& Wakenhut, R., Ed., Moral judgments and social education. New Brunswik, NJ: Transaction Publisher, pp. 259 - 271.

Hemmerling, K. (in press). Fostering moral competences of prisoners as a new approach to social rehabilitation - An intervention study. Unpublished doctoral dissertation, University of Konstanz, Department of Psychology.

Hemmerling, K., Scharlipp, M., \& Lind, G. (2009). Die Konstanzer Methode der DilemmaDiskussion für die Bildungsarbeit mit Risikogruppen. In: K. Mayer \& H. Schildknecht, Eds., Handbuch Dissozialität, Delinquenz und Kriminalität - Grundlagen und Methoden der professionellen Arbeit mit Menschen mit abweichendem Verhalten. Zurich: Schulthess Juristische Medien.

Higgins, A. (1980). Research and measurement issues in moral education interventions. In: R. Mosher, Ed., Moral education. A first generation of research and development, pp. 
92-107. New York: Praeger.

Huang, V. (2009). Laying the foundations for democratic behavior - A comparison of three different approaches to democratic education. Scientific paper in pedagogical studies, University of Konstanz, Department of Psychology. http://kops.ub.unikonstanz.de/handle/urn:nbn:de:bsz:352-opus-123672 (2.7.2011)

Ishida, C. (2006). How do scores of DIT and MJT differ? A critical assessment of the use of alternative moral development scales in studies of business ethics. Journal of Business Ethics, 67, 1, 63-74.

Jackson, P. W. (1967). Life in the classroom. New York: Holt, Rienhard \& Winston.

Jahnke, Th. \& Meyerhöfer, W., Eds. (2006). PISA \& Co - Kritik eines Programms. Verlag Franzbecker. Hildesheim 2006.

Jefferson, T. (1940). Letters (arranged by W. Whitman). Eau Claire, WI: E. M. Hale.

Juul, J. (1997). Das kompetente Kind. Auf dem Weg zu einer neven Wertgrundlage für die ganze Familie. Reinbek: Rowohlt.

Keasey, C.B. (1974). The influence of opinion-agreement and qualitative supportive reasoning in the evaluation of moral judgments. Journal of Personality and Social Psychology, 30, 477-482.

Klein, H. P. (2010). Die neue Kompetenzorientierung: Exzellenz oder Nivellierung? Zeitschrift für Didaktik der Biowissenschaften, 1, 15 - 26.

Kohlberg, L. (1964). Development of moral character and moral ideology. In M.L. Hoffman \& L.W. Hoffman, Eds., Review of Child Development Research, Vol. I, 381-431. New York: Russel Sage Foundation.

Kohlberg, L. (1987). Moralische Entwicklung und demokratische Erziehung. In: G. Lind \& J. Raschert, Eds., Moralische Urteilsfähigkeit. Eine Auseinandersetzung mit Lawrence Kohlberg über Moral, Erziehung und Demokratie, pp. 25-43. Weinheim: Beltz.

Kohlberg, L. (1995). Die Psychologie der Moralentwicklung. Frankfurt: Suhrkamp.

Koszinoffski, R. (2006). Überprüfung der pädagogisch-didaktischen Lehrkompetenz von Lehrpersonen bezüglich der Konstanzer Methode der Dilemma-Diskussion. Diploma thesis, Department of Psychology, University of Konstanz. 
KMK Kultusministerkonferenz (2008). Bildungsstandards der Kultusministerkonferenz. Erläuterungen zu Konzeption und Entwicklung. Bonn. www.kmk.org/schul/Bildungsstandards/Argumentationspapier308KMK.pdf

KMK Kultusministerkonferenz (2009). Stärkung der Demokratieerziehung. Beschluss der Kultusministerkonferenz vom 06.03.2009.

http://www.kmk.org/fileadmin/veroeffentlichungen_beschlvesse/2009/2009_03_06Staerkung_Demokratieerziehung.pdf

Landtag Baden-Württemberg (2004). Anfrage „Förderung moralischer und demokratischer Kompetenzen an den Schulen" vom 16.2.2004: Drucksache 13 / 2921.

Lenz, B. (2006). Moralische Urteilsfähigkeit als eine Determinante für Drogenkonsum bei Jugendlichen. Unpublished master thesis, Department of Psychology, University of Konstanz.

Lind, G. (1978). Wie misst man moralisches Urteil? Probleme und alternative Möglichkeiten der Messung eines komplexen Konstrukts. In: G. Portele, Ed., Sozialisation und Moral. Weinheim: Beltz, pp. 171-201.*

Lind, G. (1982). Experimental Questionnaires: A new approach to personality research. In A. Kossakowski \& K. Obuchowski, Eds., Progress in Psychology of Personality. Amsterdam: North-Holland, pp. 132-144.*

Lind, G. (1986). Cultural differences in moral judgment competence? A study of West and East European University Students. Behavior Science Research, 21 (4), 208-255.*

Lind, G. (1987). Moral competence and education in democratic society. In G. Zecha \& P. Weingartner, Eds, Conscience: An interdisciplinary approach. Dordrecht: Reidel, pp. 91-122.*

Lind, G. (1989a). Die Entwicklung moralischer Gefühle durch Vernunft und Dialog. In: G. Lind \& G. Pollitt-Gerlach, Eds., Moral in ,unmoralischer' Zeit. Zu einer partnerschaftlichen Ethik in Erziehung und Gesellschaft. Heidelberg: Asanger, pp. 7-32.*

Lind, G. (1989b). Essay Review: 'The measurement of moral judgment' by Anne Colby, Lawrence Kohlberg. Human Development, 32, 388-397.*

Lind, G. (1994). Ausgangslage, Ziele und Ansatzpunkte des DES-Projektes in NordrheinWestfalen. Qualität von Schule, Heft 4, Wiesbaden: Hessisches Institut für Bildungsplanung und Schulentwicklung, pp. 45-45. 
Lind, G. (1993). Moralerziehung als demokratische Bildung. Politisches Lernen 2/1993, pp. 20-26.*

Lind, G. (2000). The importance of responsibility-taking opportunities for self-sustaining moral development. Journal of Research in Education 10, 1, 9-15.

Lind, G. (2002). Ist Moral lehrbar? Ergebnisse der modernen moralpsychologischen Forschung. Berlin: Logos-Verlag.

Lind, G. (2004a). Unterstützung und Herausforderung: die Konstanzer Methode der Dilemmadiskussion. In: Landesinstitut für Schule, Ed., Erziehungskultur und soziales Lernen. Soest: LSW, pp. 82-108.

Lind, G. (2004b). Evaluating Civic Competences: Toward Good Assessment Practice. Contribution to the IBE/GTZ -Seminar "Determining Good Practice in Learning to Live Together", 9.-1 1. December 2003, in the International Bureau of Education (IBE), Geneva, Switzerland.*

Lind, G. (2004c). Jenseits von PISA - Für eine neue Evaluationskultur. In: Institut für Schulentwicklung PH Schwäbisch Gmünd, Ed., Standards, Evaluation und neve Methoden. Reaktionen auf die PISA-Studie. Baltmannsweiler: Schneider Verlag Hohengehren, pp. 1 - 7.

Lind, G. (2006a). Das Dilemma liegt im Auge des Betrachters. Zur Behandlung bioethischer Fragen im Biologie-Unterricht mit der Konstanzer Methode der Dilemmadiskussion. Praxis der Naturwissenschaften. Biologie in der Schule, Januar, 1/55, 2006, pp. $10-16 .^{*}$

Lind, G. (2006b). Perspektive "Moralisches und demokratisches Lernen“. In: A. Fritz, R. Klupsch-Stahlmann \& G. Ricken, Eds., Handbuch Kindheit und Schule. Neve Kindheit, neves Lernen, never Unterricht. Weinheim: Beltz, pp. 296-309.*

Lind, G. (2006c). Teilhabe an der Argumentationsgemeinschaft als Ziel der Bildung: Die Konstanzer Methode der Dilemmadiskussion. In: E. Grundler \& R. Vogt, Eds., Argumentieren in Schule und Hochschule. Interdisziplinäre Studien. Tübingen: Stauffenburg, pp. 167-175.*

Lind, G. (2008a). Teaching students to speak up and to listen to others: Cultivating moral democratic competencies. In: D. E. Lund \& P. R. Carr, Eds., Doing democracy and social justice in education: Political literacy for all students, pp. 319-335. New York: Peter Lang Publishing.* 
Lind, G. (2008b). Konstanzer Methode der Dilemma-Diskussion als methodischer Beitrag zur Werteerziehung. In: Bayrisches Staatsministerium für Unterricht und Kultus, ed., Werte machen stark. Praxishandbuch zur Werteerziehung, pp. 45-53. Augsburg: Brigg Verlag.*

Lind, G. (2008c). The meaning and measurement of moral judgment competence revisited - A dual-aspect model. In: D. Fasko \& W. Willis, Eds., Contemporary philosophical and psychological perspectives on moral Development and education, pp. 185 - 220. Cresskill. NJ: Hampton Press.

Lind, G. (2009a). Moral ist lehrbar. Handbuch zur Theorie und Praxis moralischer und demokratischer Bildung. Munich: Oldenbourg. Second expanded edition.

Lind, G. (2009b). Favorable learning environments for moral development - A multiple intervention study with nearly 3.000 students in a higher education context. Paper presented at the annual meeting of AERA in San Diego, April 13 - 17, 2009.

Lind, G. (2010). Die Förderung moralisch-demokratischer Kompetenzen mit der Konstanzer Methode der Dilemma-Diskussion. In: B. Latzko \& T. Malti, Eds., Moralentwicklung und -erziehung in Kindheit und Adoleszenz, pp. 285-302. Munich: Juventa-Verlag.*

Lind, G. (2011a). Moralerziehung. In: Kiel, E. \& Zierer, K., eds: Basiswissen Unterrichtsgestaltung. Baltmannsweiler: Schneider Verlag Hohengehren, pp. 51 - 62. *

Lind, G. (2011b). Selbst ist die Schule! Fremd- versus Selbstevaluation. Grundschule $4 / 2011,24-26$. $^{*}$

Lind, G. (2011c). Verbesserung des Unterrichts durch Selbstevaluation. Ein Plädoyer für unverzerrte Evidenz. In: J. Bellmann \& T. Müller, Eds: Wissen, was wirkt. Kritik evidenzbasierter Pädagogik. Wiesbaden: VS-Verlag für Sozialwissenschaften.*

Lind, G. (2011d). Gewalt als die niedrigste Ebene der Konfliktlösung, Ethics in Progress Quarterly, 1 (1). [2nd edition] http://ethicsinprogress.org/?page_id=135

Lind, G. \& Lind, O. (1984). Demokratie und moralische Urteilskompetenz. Vierteljahresschrift für Sicherheit und Frieden 2, pp. 2-7.*

Lind, G. \& Raschert, J., Eds. (1987). Moralische Urteilsfähigkeit - Eine Auseinandersetzung mit Lawrence Kohlberg über Moral, Erziehung und Demokratie. Weinheim: Beltz (with contributions by L. Kohlberg, A. Higgins, G. Lind, G. Nunner-Winkler, F. Oser). 
Lind, G., Sandberger, J.-U. \& Bargel, T. (2010). Moral competence and democratic personality. In G. Lind, H.A. Hartmann \& R. Wakenhut, Eds., Moral judgment and social education. New Brunswik, NJ: Transaction Publisher, S. 55-77. (2 ${ }^{\text {nd }}$ edn.)

Linn (2000). Assessments and accountability. Educational Researcher, 29, No. 2, pp. 4-16. Lupu, I. (2009). Moral, Lernumwelt und Religiosität. Die Entwicklung moralischer Urteilsfähigkeit bei Studierenden in Rumänien in Abhängigkeit von Verantwortungsübernahme und Religiosität. Unpublished dissertation, Department of Psychology, University of Konstanz. http://kops.ub.uni-konstanz.de/handle/urn:nbn:de:bsz:352-opus-95865.

Mansbart, F.-J. (2001). Motivationale Einflüsse der moralischen Urteilsfähigkeit auf die Bildung von Vorsätzen. Unpublished diploma thesis, Department of Psychology, University of Konstanz.

McFaul, M. (2004). Democracy promotion as a world value. The Washington Quarterly, $28,1,147-163$.

MKJS - Ministerium für Kultus, Jugend und Sport Baden-Württemberg (2004). Förderung moralischer und demokratischer Kompetenzen an den Schulen. Drucksache 13 / 2921; 13. Wahlperiode 16. 02. 2004.

Moll, J., de Oliveira-Souza1, R., Eslinger, P. J., Bramatil, I. E., Mourão-Mirandal, J., Andreiuolo, P. A., \& Pessoa, L. (2002). The neural correlates of moral sensitivity: A functional magnetic resonance imaging investigation of basic and moral emotions. The Journal of Neuroscience, 22 (7), 2730-2736.

Nichols, S. L. \& Berliner, D. (2006). Collateral damage: How high-stakes testing corrupts schools. Cambridge, MA: Harvard Education Press.

Nowak, E. \& Lind, G. (2009). Mis-educative martial law - The fate of free discourse and the moral judgment competence of Polish university students from 1977 to 1983. In: M. Zirk-Sadowski, B. Wojciechowski, \& M. Golecki, Hg., Between complexity and chaos. Torun, Poland: Adam Marszalek publisher, pp. 129-152.

Nussbaum, M. C. (2006). Frontiers of justice. Disability, nationality, species membership. Cambridge, MA: The Belknap Press of Harvard University.

Oser, F. \& Althof, W. (1994). Moralische Selbstbestimmung. Modelle der Entwicklung und Erziehung im Wertebereich. Stuttgart: Klett-Cotta (2nd edn.)

Piaget, J. (1973). Das moralische Urteil beim Kinde. Frankfurt: Suhrkamp (Original 1932). 
Pittel, S. M. \& Mendelsohn, G. A. (1966). Measurement of moral values: a review and critique. Psychological Bulletin, 66, 22-35.

Portele, G. (1978). „Du sollst das wollen!" Zum Paradox der Sozialisation. In: G. Portele, Ed., Sozialisation und Moral.Weinheim: Beltz, pp. 147-168.

Power, F.C., Higgins, C. \& Kohlberg, L. (1989). Lawrence Kohlberg's approach to moral education. New York: Columbia University Press.

Prehn, K., Wartenburger,I., Mériau, K., Scheibe, C., Goodenough, O.R., Villringer, A., van der Meer, E., \& Heekeren, H.R. (2008). Influence of individual differences in moral judgment competence on neural correlates of socio-normative judgments. Social Cognitive and Affective Neurosience. 3(1), 33-46.

Radbruch, G. (1987). Rechtsphilosophie, Gesamtausgabe, Band 13. ed. Arthur Kaufmann. Heidelberg: C. F. Müller.

Reinhardt, S. (1980). Moralisches Urteil im politischen Unterricht. Gegenwartskunde, 29(4), 449-460.

Rest, J. R. \& Thoma, S. J. (1985). Relation of moral judgment development to formal education. Developmental Psychology, 21 , 709-714.

Roth, H. (1981). Moralische Mündigkeit als Ziel der Erziehung. In L. Mauermann \& E. Weber, Eds., Der Erziehungsauftrag der Schule. Beiträge zur Theorie und Praxis moralischer Erziehung unter besonderer Berücksichtigung der Wertorientierung im Unterricht. Donauwörth: Auer.

Roth, R. (2010). Bürgermacht: Eine Streitschrift für mehr Partizipation. Hamburg: Edition Köperstiftung.

Saeidi-Parvaneh, S. (2011). Moral, Bildung und Religion im Iran - Zur Bedeutung universitärer Bildung für die Entwicklung moralischer Urteils- und Diskursfähigkeit in einem religiös geprägten Land. Dissertation, Department of Psychology Univeersity of Konstanz. http://kops.ub.uni-konstanz.de/volltexte/2011/13107/

Schillinger, Marcia (2006). Learning environments and moral development: How university education fosters moral judgment competence in Brazil and two Germanspeaking countries. Aachen: Shaker-Verlag.

Schläfli, A., Rest, J. R. \& Thoma, S. J. (1985). Does moral education improve moral judg- 
ment? A meta-analysis of intervention studies using the Defining Issues Test. Review of Educational Research, 55, 319-352.

Schwartz, S.H. \& Bardi A. (2001). Value hierarchies across cultures. Journal of Cross-Cultural Psychology, Vol. 32, 268-290.

Seitz, C. (1991). Demokratiefähigkeit und moralisches Urteilen bei Schülern - Ein Vergleich von einheimischen und Aussiedlerkindern. Unpublished diploma thesis Department of Psychology, University of Konstanz.

Sen, A. K. (1999). Democracy as a universal value. Journal of Democracy, 10 (3), 3 - 17.

Sen, A. K. (2010). Die Idee der Gerechtigkeit. Munich: Beck Verlag.

Tiedemann, M. (2011). Philosophiedidaktik und empirische Bildungsforschung. Möglichkeiten und Grenzen. Münster: Lit Verlag.

Treichel, D., 2003: Moralische Entwicklung. Interview with Prof. Dr. Georg Lind, University of Konstanz. DVD, ca. 2 hrs; Order from: tomcom GmbH, Heuridweg 14, 88131 Lindau. Loan: Uni-Bibliothek Konstanz; Signatur 6/ psy247//46b.

Uhl, S. (1986). Die Mittel der Moralerziehung und ihre Wirksamkeit. Bad Heilbrunn: Klinkhardt.

Waal, F. de (2009). Primates and philosophers: How morality evolved. Edited by Stephen Macedo \& Josiah Ober. Princton, NJ: Princeton University Press.

Wasel, W. (1997). Wir können auch anders: Willentliche Kontrolle stereotypen Denkens. University of Konstanz, Department of Psychology, unpublished dissertation.

Weiß, S. \& Zierer, K. (2010). Der MUT (Moralisches-Urteil-Test). In: K. Zierer, Ed., Kompendium „Schulische Werteerziehung“. Baltmannsweiler Schneider Verlag Hohengehren, pp. 238-246.

Zierer, K. (2008). Und die Moral von der Geschicht - Moralerziehung durch DilemmaDiskussionen in der Grundschule. Erziehung und Unterricht, 2008, Heft 3 / 4, 285-293.

Internet-Addresses

"Promotion of moral and democratic competence": http://www.uni-konstanz.de/agmoral/

The use of the KMDD in various subjects and disciplines: 
http://www.uni-konstanz.de/ag-moral/moral/kmdd-references_teaching_subjects.htm Literature on the KMDD: http://www.uni-konstanz.de/ag-moral/moral/kmddreferences.htm

\section{About the author}

Dr. Georg Lind, born 1947, is professor of Psychology, has developed the Moral Judgment Test (MJT) for measuring moral competence and moral orientations simultaneously, and the Konstanz Method of Dilemma-Discussion (KMDD) ${ }^{\circledR}$. From 1972 to 2010, he taught and did research at the University of Konstanz, Germany. During that time he was also guest professor at the Humboldt University Berlin, the University of Illinois at Chicago, and the Universidad de Monterrey, Mexico. He is now retired but is still active in research and teaching, giving lectures and workshops in many countries. His main area of research was and still is moral and democratic development and education. His website informs about his publications and research interests: http://www.uni-konstanz.de/ag-moral/ 